\title{
Adjustment coefficients for planimetric analysis of the granulometry of coarse-grained sediments
}

\author{
Małgorzata Pisarska-Jamroży ${ }^{1, *}$, Tomasz Kossowski \& Jerzy Jamroży ${ }^{3}$ \\ ${ }^{1}$ Institute of Geology, Adam Mickiewicz University, Maków Polnych 16, 61-606 Poznań, Poland; \\ e-mail: pisanka@amu.edu.pl \\ 2Institute of Socio-Economic Geography and Spatial Management, Adam Mickiewicz University, Dzięgielowa 27; \\ 61-680 Poznań; e-mail: tkoss@amu.edu.pl \\ ${ }^{3}$ Poznań Supercomputing and Networking Centre affiliated to the Institute of Bioorganic Chemistry of the Polish \\ Academy of Sciences, Noskowskiego 10, 61-704 Poznań; e-mail: jamrozy@man.poznan.pl \\ "corresponding author
}

\begin{abstract}
The relationship between results from granulometric analyses of by sieving and by planimetry was investigated by numerical simulation of cubes filled with boulders, cobbles and pebbles. Cross-sections through the sediment were simulated and compared with photos of an actual outcrop wall. Volumes estimated on the basis of planimetric analysis using the cross-sections were compared with sieve analyses, thus allowing to determine adjustment coefficients. The coefficients for pebbles and cobbles have a small standard error, but are larger for boulders, which might be a consequence of too small areas formed by the cross-sections.
\end{abstract}

Keywords: grain-size distribution, planimetric analysis, coarse-grained sediments

\section{Introduction}

A method for determining the grain-size distribution of coarse sediments like debrisflow deposits has never been standardised. It is usually assessed through analysis of the matrix (finer fraction) or by estimation (Casagli et al., 2003). Sieving coarse-grained sediments is labour-intensive and time-consuming, and it sometimes hard to perform, for instance in the case of consolidated material. The results tend to depend on the researcher's experience and may therefore not necessarily be representative (i.e., other researchers may obtain different results).

This problem was mentioned for the granulometric analysis of fluvial gravels by Wol- man (1954), Leopold (1970), Kellerhals \& Bray (1971), Church et al. (1989), Wohl et al. (1996), Verdú et al. (2005), Haschenburger et al. (2007) and Dugdale et al. (2010). A literature search indicates that two main sampling methods are commonly combined: planimetric analysis and the traditional sieve analysis.

Photographic planimetric analytical methods were developed, tested and discussed by Adams (1979), Ibbeken \& Schleyer (1986), Rutkowski (1995) and Graham et al. (2005). Verdú et al. (2003) were the first to present a method for automated grain-size analysis in a study that applied semi-variance to estimate the grain-size distribution. Carbonneau et al. (2004, 2005) and Buscombe et al. (2010) have demonstrated that automated image proces- 
sing can be used to measure the median grain size of sediments.

Practically all coarse-grained sediment consists of a framework of larger particles in a finer-grained matrix. The framework can contain boulders $(>256 \mathrm{~mm})$, cobbles $(256-64$ $\mathrm{mm})$, pebbles $(64-4 \mathrm{~mm})$, and granules (4-2 $\mathrm{mm})$. The matrix consists of commonly of sand $(0.0625-2 \mathrm{~mm})$, silt $(0.02-0.0625 \mathrm{~mm})$ and clay $(<0.02 \mathrm{~mm})$. A grain diameter of $2 \mathrm{~mm}$ was considered by Udden (1914) and Wentworth (1922) as a more or less natural boundary between matrix and framework in coarse-grained deposits .

In the case of grains smaller than $4 \mathrm{~mm}$, sieving is most commonly used. The minimum weight of a sample containing fine-grained gravel (granules) and coarse-grained sand is $500 \mathrm{~g}$ (e. g. standard PN-86/ B-02480). The portion of a given size fraction is defined as the percentage of its weight in relation to that of the whole sample. Ferguson \& Paola (1997) suggested a sample size for sands $0.1-10 \mathrm{~kg}$, but they pointed out that a problem may arise in the case of gravel due to the wide range of sizes and the commonly lower degree of sorting if compared with sands. The sample-size criteria proposed by De Vries (1970) and Church et al. (1989) may even require samples of many tonnes.

In the case of coarse-grained sediments, it is also possible, however, to apply photographic planimetry; this method is based on a photo of the sediment (made perpendicularly to the outcrop wall). A square of $2 \times 2 \mathrm{~m}$ or $5 \times 5 \mathrm{~m}$ of the wall is used to calculate (on the basis of the photo) the percentage taken by the area occupied by the particles (boulders and cobbles) that constitute the framework. In the next step, a square of $0.5 \times 0.5 \mathrm{~m}$ is used to calculate the percentage of the area taken by pebbles. A more detailed photo can be used for the purpose. The maximum grain size of individual particles is indicated on the photos by one (the longest visible) axis.

In contrast to sieve analyses, not all particles on the photo need to be measured. The exact method for calculating the surface areas covered by a specific grain-size fraction has been described by Rutkowski (1995). We assume that the average density of all grain fractions is the same and that, consequently, the weight percentage of a specific size fraction equals the calculated volume percentage. Alternatively commercial software can be used for the purpose.

The planimetry-derived results are error-laden because the volume of each grain-size fraction is underestimated for three reasons: (1) the photo shows a single, random cross-section of the framework particles, (2) smaller particles are less probably exposed on the photo, and (3) grains may be partially hidden on the photo by other grains, causing them to be attributed to a smaller grain-size fraction.

The objective of the present contribution is to determine whether the percentage of the areas occupied in a cross-section by a specific grain-size fraction can be used for estimating its volume percentage, or whether an adjustment coefficient is required. A similar microscopic method was used for fine-grained sediments by Merta (1991). The relationships between fine-grained grains and their images in thin section were investigated also by Krumbein (1935), Greenman (1951), Packham (1955) and Kellerhals et al. (1975). This planimetric method is also commonly used in petrology to determine the petrographical composition and grain-size of lithified sediments (Ratajczak \& Tumidajski, 1979). As far as we know, no analysis has, however, been published as yet regarding the relationship between the area covered by a coarse-grained framework on a photo and the volume percentage of the framework. The methods cited above are all based on comparison of a model to actual sieve results. In contrast, our method applies a purely mathematical simulation on the basis of exactly known volumes of each of size fractions. Advantages of our method are not only that any subjective interpretation is avoided, but also that the calculations are based on much larger (virtual) sediment samples than can actually be sampled in the field.

\section{Methods}

The numerical simulations applied here have been employed to generate cubes with an 
edge length of $5 \mathrm{~m}$. These cubes were virtually filled by grains belonging to three grain-size fractions: (1) >256 mm, (2) 64-256 mm and (3) 4-64 mm (Fig. 1). Five cubes were simulated; they contained virtual volumes of the three grain-size fractions of, respectively: (1) $5 \%, 5 \%$, $10 \%$, (2) $5 \%, 10 \%, 12 \%$, (3) $10 \%, 10 \%, 15 \%$, (4) $10 \%, 15 \%, 5 \%$ and (5) 15\%, 20\%, 20\% (Table 1). All these particles had to fit entirely within the cubes.

In order to simulate distributions of the various fractions within the cubes in a random way, two conditions had to be fulfilled.

Firstly, a randomly chosen grain radius $r$ was selected, using a random number generator with continuous uniform distribution $U$ with parameters $a$ and $b$ (i.e. continuous uniform distribution - probability distribution of random number selection from the continuous interval between $a$ and $b$ ) defining the left and right end of the range, i.e. the smallest and the largest possible sizes of a fraction. Because these parameters depend on the boundaries between the three grain-size fractions, three continuous, uniform distributions were obtained: $U$ (1024, $128), U(32,128)$ and $U(2,32)$.

Then, as a second step, the positions of the centres of the grains were chosen randomly, assuming that their $X, Y$ and $Z$ co-ordinates are continuous random variables with identical independent uniform distributions $U(0$, 5000). Because the centre of a randomly selected grain should not be located closer to a wall of the cube than the length of its radius, $r$, the coordinate distributions depend on this radius. Thus, the adjusted distributions of coordinates have the form $U(r, 5000-r)$.

The method of generating granules within the cube described above was used in a simulation algorithm, which consists of the following steps:

1. set the maximum cumulative volume for grain-size fraction I $(F V I)$;

2. set the maximum cumulative volume for grain-size fraction II (FVII);

3. set the maximum cumulative volume for grain-size fraction III (FVIII);

4. set granule empty;
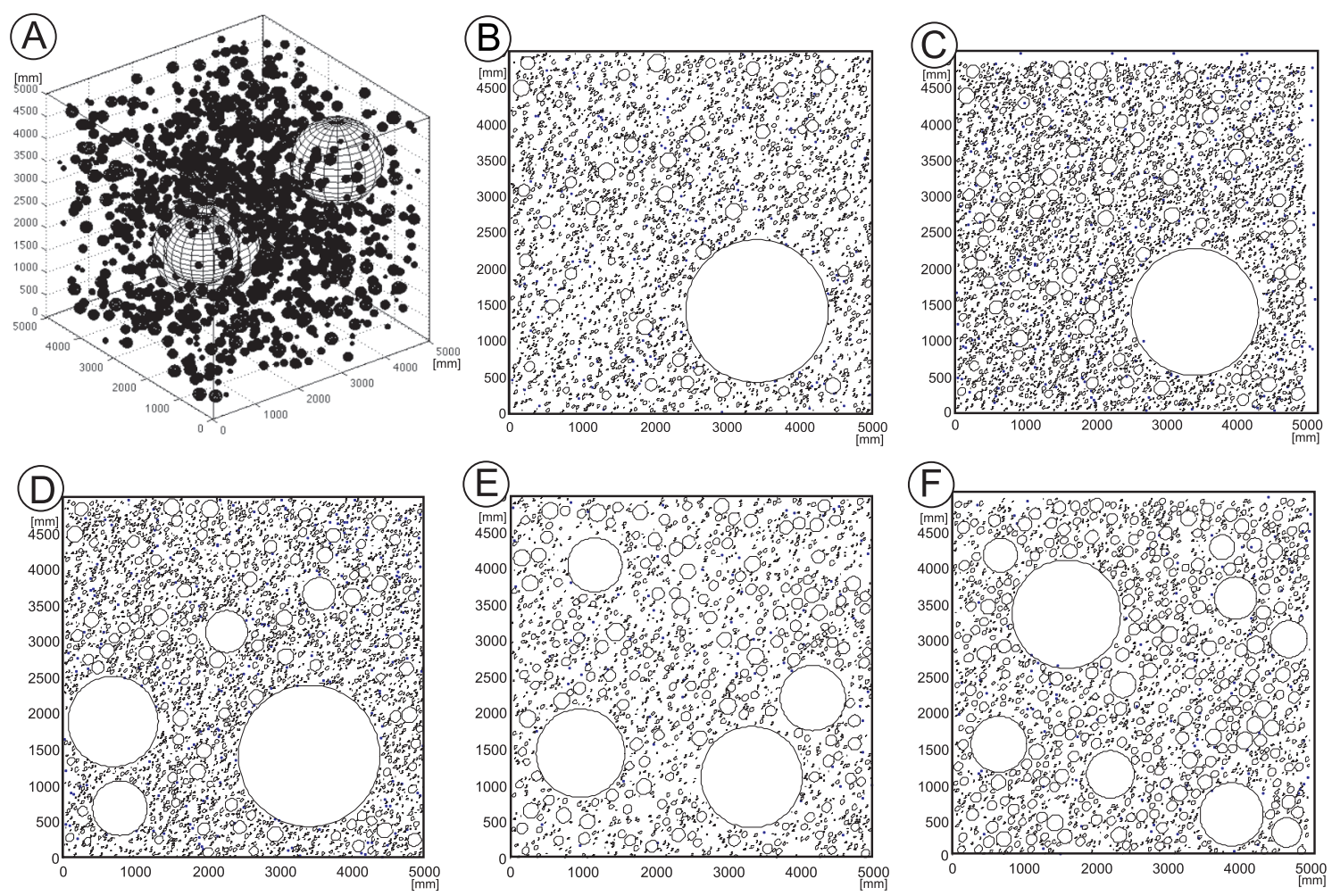

Fig. 1. Set-up of the investigation of the planimetric grain-size analysis.

A: The cube virtually filled with ballshaped grains used for calculations. Length of cube edge is $5 \mathrm{~m}$; B-F: Examples of the cross-sections of the cubes used in five successive set-ups. 
Table 1. Results of the analysis.

\begin{tabular}{|c|c|c|c|c|c|c|}
\hline Set-up & $\begin{array}{c}\text { Grain-size fraction } \\
{[\mathrm{mm}]}\end{array}$ & $\begin{array}{c}\text { Initial set-up } \\
{[\%]}\end{array}$ & $\begin{array}{c}\text { Final set-up } \\
{[\%]}\end{array}$ & $\begin{array}{c}\text { Number of } \\
\text { generated grains }\end{array}$ & $\begin{array}{c}\text { Volume of } \\
\text { generated grains } \\
{[\%]}\end{array}$ & $\begin{array}{c}\text { Average area } \\
\text { covered } \\
\text { on cross-section } \\
{[\%]}\end{array}$ \\
\hline \multirow{3}{*}{ I } & boulder $>256$ & 5 & 5 & 3 & 6.45 & 7.09 \\
\hline & cobble $64-256$ & 5 & 5 & 2423 & 5.00 & 5.11 \\
\hline & pebble 4-64 & 10 & 10 & 524645 & 10.00 & 9.99 \\
\hline \multirow{3}{*}{ II } & boulder $>256$ & 5 & 5 & 3 & 5.07 & 5.63 \\
\hline & cobble $64-256$ & 10 & 10 & 5599 & 10.00 & 10.09 \\
\hline & pebble 4-64 & 12 & 12 & 795398 & 11.57 & 11.88 \\
\hline \multirow{4}{*}{ III } & boulder $>256$ & 10 & 10 & 12 & 10.45 & 11.55 \\
\hline & cobble $64-256$ & 10 & 10 & 5822 & 10.00 & 10.09 \\
\hline & pebble 4-64 & 15 & 11 & 691456 & 10.56 & 10.52 \\
\hline & boulder $>256$ & 10 & 10 & 26 & 10.10 & 10.86 \\
\hline \multirow[t]{2}{*}{ IV } & cobble $64-256$ & 15 & 15 & 11263 & 15.00 & 14.96 \\
\hline & pebble 4-64 & 5 & 5 & 231711 & 4.75 & 5.01 \\
\hline \multirow{3}{*}{ V } & boulder $>256$ & 15 & 15 & 65 & 15.04 & 16.36 \\
\hline & cobble $64-256$ & 20 & 20 & 23933 & 20.00 & 19.05 \\
\hline & pebble 4-64 & 20 & 4 & 259002 & 4.23 & 5.13 \\
\hline
\end{tabular}

5. generate one grain $(\mathrm{G})$ from fraction I and write it to granule;

6. new value of volume = volume of $\mathrm{G}$;

7. while volume $<F V I$

generate grain $\mathrm{G}$ from fraction I;

if $G$ doesn't share any part with any element of granule,

write $G$ to granule;

end if;

new value of volume $=$ volume + volume of $\mathrm{G}$; end while;

8. set volume $=0$;

9. repeat steps 7 and 8 for the grain-size of fraction II and of fraction III.

The algorithm has been implemented in Matlab and Octave. Matlab software system is commonly used in grain-size distribution experiments (Carbonneau, 2006; Barnard et al., 2007). Due to the long time that the simulation takes, it was independently run on computers in the Spatial Econometrics Laboratory of Adam Mickiewicz University, and in the Poznań Supercomputing and Networking Centre (affiliated to the Polish Academy of Sciences).

The cubes filled with the virtual grains were used to simulate images representing crosssections through the cubes. Each cube was divided by nine planes parallel to one of its walls, thus leaving distances between these planes of $500 \mathrm{~mm}$. These planes, which crossed grains of the various fractions were treated as 'photos'. Each 'cut' grain was attributed with the length of its 'real' diameter (as chosen during the block simulation) and the length of the diameter of the corresponding circle in the image. Based on these parameters, the grain-size distributions visible in the cross-sections could be compared with the 'real' values given for the grain sizes in the simulated cubes.

\section{Results}

We started our simulations with five initial set-ups (see Table 1), which had then to be modified because of the restrictions for the volume of the smallest granules. In the case of assumptions III and V, achieving the assumed volume of the smallest grains was not possible due to lack of space. The initial set-ups were consequently changed into final set-ups with reduced volumes of the various grain-size fractions. The generated volume of grains in each fraction therefore differed slightly from the final set-ups, but it should be emphasised here that these differences were not significant (see the volume of generated grains in Table 1).

Each cross-section was analysed according to the method proposed by Rutkowski (1995), which allows the calculation of the surface area 
Table 2. Computed regression coefficients for the various framework grain-size fractions.

\begin{tabular}{ccc}
\hline $\begin{array}{c}\text { Grain-size } \\
\text { fraction } \\
{[\mathrm{mm}]}\end{array}$ & $\begin{array}{c}\text { Regression } \\
\text { coefficient }\end{array}$ & $\begin{array}{c}\text { Standard } \\
\text { error }\end{array}$ \\
\hline boulders $>256$ & 0.83 & 0.0392 \\
cobbles 64-256 & 1.01 & 0.0121 \\
pebbles 4-64 & 0.98 & 0.0086 \\
\hline
\end{tabular}

covered by grains in a specific size fraction. Knowing the real values for the volumes of the generated grains visible in the cross-sections, it was possible to compute the regression coefficient (a) for ratio (in percentages) between the occupied volume $(\mathrm{V})$ and the surface area $(\mathrm{P})$ in the cross-sections. For each grain-size fraction this relation is:

$$
\mathrm{V}_{\mathrm{i}}=\mathrm{a}_{\mathrm{i}}^{*} \mathrm{P}_{\mathrm{i}}
$$

The results presented in Table 1 show the actual volume of generated grains of each size fraction and the corresponding surface area in the cross-sections. Table 2 shows the computed regression coefficients $\left(a_{i}\right)$ for each fraction. The coefficients were calculated using the least squares method, and they were statistically significant (standard error at level 0.0001). The results were obtained on the basis of the values for 50 grains in each size fraction. We used 9 cross-sections for each cube with simulated grains and, in addition, the sum of the crosssections for each cube. Because the simulations were applied to different initial/final set-ups, our results may be considered as applicable to other cases that were not analysed, so that the estimated coefficients can reliably be used to determine the volume of the grains visible on the photos.

\section{Conclusions}

It appears possible to derive the actual volume of the framework constituents (pebbles, cobbles, boulders) in a coarse-grained sediment from pictures of the wall of an outcrop, but for boulders an adjustment coefficient (a) is required.

The adjustment coefficients for cobbles and pebbles have a relatively small standard error and are close to $\mathrm{a}=1$, indicating that a straight relationship exists between the percentage of the surface area covered on a photo by grains belonging to a specific size fraction and the volume percentage actually occupied by the grains of this size fraction. This implies that no adjustment coefficient need be applied for deriving the volume percentage from the surface areas on the photos.

The larger standard error for the adjustment coefficient for boulders might be caused by a surface area on the photo that is too small. The relationship between the surface areas of single grains in the cross-sections and that of the whole cross-section area depends relatively strongly on variations in the random distribution of grains of a particular size.

The adjustment coefficient for boulders (0.83) differs substantially from 1, implying that the planimetric method without application of an adjustment coefficient causes a significant error in the estimation of the volume percentage of the boulders

The grain-size analysis of coarse-grained sediments should be performed in two phases. In the first phase, a standard sieve analysis should be performed for grains smaller than pebbles. The minimum sample weight should be $500 \mathrm{~g}$. In the second phase, photographic planimetry can be applied to calculate the proportions of pebbles, cobbles and boulders, which should sum up to $100 \%$. For boulders, an adjustment coefficient of 0.83 should be used.

\section{References}

Adams, J., 1979. Gravel size analysis from photographs. Journal of the Hydraulics Division 10, 1247-1255.

Barnard, P.L., Rubin, D.M., Harney, J. \& Mustain, N., 2007. Field test comparison of an autocorrelation technique for determining grain size using a digital 'beachball' camera versus traditional methods. Sedimentary Geology 201, 180-195.

Buscombe, D., Rubin, D.M. \& Warrick, J.A., 2010. A universal approximation of grain size from images of noncohesive sedyment. Journal of Geophysical Research 115, doi:10.1029/2009JF001477.

Carbonneau, P.E., Lane, S.N. \& Bergeron, N.E., 2004. Catchment-scale mapping of surface grain size in gravel-bed rivers using airborne digital imagery. $\mathrm{Wa}$ ter Resources Research 40, doi:10.1029/2003WR002759. 
Carbonneau, P.E., Bergeron, N.E. \& Lane, S.N., 2005. Automated grain size measurements from airborne remote sensing for long profile measurements of fluvial grain sizes. Water Resources Research 41, doi:10.1029/2005WR003994.

Carbonneau, P.E., Lane, S.N. \& Bergeron, N.E., 2006. Feature-based image processing methods applied to bathymetric measurements from airborne remote sensing in fluvial environments. Earth Surface Processes and Landforms 31, 1413-1423.

Casagli, N., Ermini, L. \& Rosati G., 2003. Determining grain size distribution of the material composing landslide dams in the Northern Apennines: sampling and processing methods. Engineering Geology 69, 83-97.

Church, M.A., McLean, D.G. \& Wolcott, J.F., 1989. River bed gravels: sampling and analysis. [In:] C.R. Thorne, J.C. Bathurst \& R.D. (Eds): Sediment transport in gravelbed rivers. Wiley, Chichester, 43-88.

De Vries, M. 1970. On the accuracy of bed-material sampling. Journal of Hydraulics Research 8, 523-533.

Dugdale, S.J., Carbonneau, P.E. \& Campbell, D., 2010. Aerial photosieving of exposed gravel bars for the rapid calibration of airborne grain size maps. Earth Surface Processes and Landforms 35, 627-639.

Graham D.J., Rice S.P. \& Reid I., 2005. A transferable method for the automated grain sizing of river gravels. $\mathrm{Wa}$ ter Resources Research 41, doi:10.1029/2004WR003868.

Greenman, N.N., 1951. The mechanical analysis of the sediments from thin-section data. Journal of Geology 59, 447-462.

Haschenburger, J.K., Rice, S.P. \& Voyde, E., 2007. Evaluation of bulk sediment sampling criteria for gravel-bed rivers. Journal of Sedimentary Research 77, 415-423.

Ibbenken, H. \& Schleyer, R., 1986. Photo-sieving: a method for grain-size analysis of coarse-grained, unconsolidated bedding surfaces. Earth Surface Processes and Landforms 11, 59-77.

Kellerhals, R. \& Bray, D.I., 1971. Sampling procedures for coarse fluvial sediments. Proceedings of the American Society of Civil Engineers, Journal of the Hydraulics Division 97, 1165-1179.

Kellerhals, R., Shaw, J. \& Arora, V.K., 1975. On grain size from thin section. Journal of Geology 84, 75-96.

Krumbein, W.C., 1935. Thin-section mechanical analysis of indurated sediments. Journal of Geology 43, 482496.

Leopold, L.B., 1970. An improved method for size distribution of stream bed gravel. Water Resources Research 6, 1357-1366.

Merta, T., 1991. A new, universal method of thin-section - to - sieve transformation of granulometric data. Acta Geologica Polonica 41, 117-148.
Packham, G.H., 1955. Volume, weight and number frequency analysis of sediments from thin-section data. Journal of Geology 63, 50-58.

PN-86/ B-02480. Polska norma. Grunty budowlane. Określenia, symbole, podziat i opis gruntów [Polish standard. Building soils. Definitions, symbols, division and description of building soils], $19 \mathrm{pp}$.

Ratajczak, T. \& Tumidajski, T., 1979. Analiza geometryczna skał na podstawie obserwacji mikroskopowych. [Geometrical analysis of rocks on the basis of microscopic observations]. [In:] A. Bolewski \& W. Żabiński (Eds): Metody badań mineratów i skat [Methods for the investigation of minerals and rocks]. Wydawnictwo Geologiczne, Warszawa, 290-307.

Rutkowski, J., 1995. Badania uziarnienia osadów bardzo gruboziarnistych [Investigation of the granulometry of very coarse-grained sediments]. [In:] E. MycielskaDowgiałło \& J. Rutkowski (Eds): Badania osadów czwartorzędowych. Wybrane metody i interpretacja wyników [Investigation of Quaternary sediments. Some methods and interpretation of the results]. WGiSR UW, Warszawa, 106-114.

Udden, J.A., 1914. Mechanical composition of clastic sediments. Geological Society of American Bulletin 25, 655-744.

Verdú, J.M., Batalla, R.J. \& Martínez-Casasnovas, J.A., 2003. Estimating grain-size distributions of a gravel riverbed at reach scale from detailed aerial photos, geostatistics and digital image processing (Isábena River, Spain). Paper presented at the Braided Rivers Conference, British Geomorphological Research Group (London, April 2001), Poster.

Verdú, J.M., Batalla, R.J. \& Martínez-Casasnovas, J.A., 2005. High-resolution grain-size characterisation of gravel bars using imagery analysis and geo-statistics. Geomorphology 72, 73-93.

Wentworth, C.K.A., 1922. A scale of grade and class terms for clastic sediments. Journal of Geology 30, 377-392.

Wohl, E.E., Anthony, D.J., Madesen, S.W. \& Thompson, D.M., 1996. A comparison of surface sampling methods for coarse fluvial sediment. Water Resources Research 32, 3219-3226.

Wolman, M.G., 1954. A method of sampling coarse river bed material. Transactions American Geophysical Union 35, 951-956.

Manuscript received: 10 March 2011 Revision accepted: 14 September 2011 